\title{
SUSTAINABILITY: CHALLENGES AND OPPORTUNITIES FOR THE METALLURGICAL INDUSTRY
}

\author{
Daniel GAUDE-FUGAROLAS
}

dgaude Prime Innovation SLU, Vilassar de Mar, Spain, EU, dgaude@cantab.net

https://doi.org/10.37904/metal.2019.773

\begin{abstract}
At present, climate change, sustainability, resource use and greenhouse gas emissions are issues that cannot be avoided. Undeniably, the impact of human activity unbalances many natural processes and it is producing effects on the planet's climate, ecosystems and people's health that are unprecedented.

If we look into $\mathrm{CO}_{2}$ emissions, industry produces about one third of non-agricultural emissions, and of that, more than half is due to materials production (mainly steel and cement). Additionally, as population grow and people become richer, the demand for new products, services and energy will also increase.

If climate change targets are to be met (roughly, a reduction of $50 \%$ in $\mathrm{CO}_{2}$ emissions in 2050 with respect to the present), even with the increase in demand taken into account, a measure of serene and profound reflection is needed.

This article looks into some of the challenges and the opportunities that the metallurgical industry faces in the coming years and decades, related to the use of resources and energy, the efficiency of processes, and the emissions and waste produced.
\end{abstract}

Keywords: Sustainability, emissions, energy, $\mathrm{CO}_{2}$, metallurgical industry

\section{INTRODUCTION}

The influence of human activity on the planet is undeniable. Resource depletion, excess energy generation, waste and pollution are some of the by-products of the industrialised civilization we live in. The consequences are already being felt, not only on various ecosystems, but also in the disruption of logistic chains and everyday life caused by extreme weather, droughts, floods and storms. As the option of going back in time is not feasible, different and more realistic actions need to be considered [1-2].

According to the Intergovernmental Panel on Climate Change (IPCC), in order to limit global warming to less than $2{ }^{\circ} \mathrm{C}$, total emissions from industry should be reduced by $50 \%$ to $80 \%$ by 2050 . A more desirable target of $1.5{ }^{\circ} \mathrm{C}$ however, would require a reduction of emissions closer to $75 \%$ to $90 \%$ [2].

On the other hand, with the planet's population expected to rise from 7.5 to 9.5 billion by 2050 and the middle class population raising from 1 to 4 billion, the demand for steel is expected to double in that period. Therefore, the target for the steel industry should be to double production while (at least) halving its $\mathrm{CO}_{2}$ emissions. Similar targets would be necessary in aluminium and other metallurgical industries [3].

This article looks into some of the challenges and the opportunities that the metallurgical industry faces in the coming years and decades, related to the use of resources and energy, the efficiency of processes, and the emissions and waste produced.

\section{FROM ORE TO PRODUCT}

In order to achieve a positive contribution to the IPCC goals, the energy, resource use and emissions footprint of the steel industry needs to be analysed across the whole process, from ore extraction to product end-of-life management. Starting with the primary steel production, we are aware that although the metal content in ore 
is fixed, and already extracted at high efficiency, as richer deposits become depleted, progressively lower metal content in that ore is to be expected. However, the metal industry is already very efficient in extracting it, to the point that the ore to liquid metal process is relatively close to the thermodynamic limit of $6.7 \mathrm{GJ} /$ tonne of steel. [5-8]

On the other hand, recycled steel uses about $50 \%$ of the energy compared to that produced from ore. Although newly mined metal will still needed to cope with rising demand, recycling rates should be increased and its logistics optimised. Besides end-of-life metal, a large portion of the scrap metal is actually a by-product within the manufacturing process. Better design could reduce the amount of internal recycling, and therefore the use of resources, energy and emissions involved. Additionally, conceiving applications for manufacturing from scrap metal without the need to melt it may lead to energy savings of $90 \%$ with respect to primary steel. Processes, energy use and product design all need to be assessed and their efficiency maximised to produce products that use less metal, last longer and are easier to reuse or recycle. [5-8]

\section{BETTER ENERGY USE}

\subsection{Avoid wasting it}

Steelmaking is a very energy intensive industry. Energy is needed all throughout the production but it is also a source of emissions and therefore reducing the amount of energy used and decarbonising it does have a large impact on the industry's footprint. In order to improve the use of energy, a better design of steel products and intermediate processes, like reducing the amount of manufacturing scrap metal, could facilitate the reduction of the total energy required to obtain the final product. Similarly, much of the energy use is related to reheating metal prior to a new treatment or production stage. Therefore, by redesigning production lines, industry could avoid some of the energy waste involved to that reheating. Finally, by using the remaining useful energy on that heat, some extra energy could also be saved.

Exergy is defined to be the maximum useful energy we can extract from some source of energy. Energy is conserved. Exergy is not. An assessment of exergy fluxes needs to be performed for each process. As a steelmaking industry average, around a $10 \%$ of exergy could be recovered.[9]

To make the most of available exergy requires some degree of redesigning of the steelmaking facilities. Some measures include avoiding unnecessary thermal cycles (avoid cooling an intermediate product to heat again later on in next manufacturing stage). For instance continuous casting can be connected to rolling (savings of 2-3GJ/t) [3, 5-8]; implementing when possible quench and self-tempering treatments (savings of 1-1.5 GJ/t); and recovering the available energy contained in emitted gases, both to generate electricity or to be used as fuel. Heat recovery from liquid metal or solids is also possible, but more difficult and less efficient. [5-8]

\subsection{Use better and cleaner of it}

Additional measures should aim to reduce the emissions related to the industry's energy sources. First, ensuring the energy purchased comes from low or zero emissions sources when possible. Then, applying additional measures specific to each of the stages of the steelmaking process. For instance: a fraction of the coke in a blast furnace can be substituted by pulverised coal or natural gas, which produce less emissions and are also cheaper. Coke-making emissions contain $\mathrm{CO}$ and $\mathrm{H}_{2}$ that can also be used as fuel. In many cases, the slag remaining from steelmaking can be used in cement production, leading to savings of up to $2 \mathrm{GJ} / \mathrm{t}$ in that industry. Ensuring the highest efficiency in furnaces, by running them continuously, with better insulation, better control of fuel to air (or even using oxygen instead), setting up heat recovery in all exhausts, and some other measures make it possible to reach a $70 \%$ of heat efficiency [5-8]. 


\section{BEYOND THE STANDARD PROCESS}

More innovative ideas may also contribute to the reduction of steelmaking footprint. For instance, why not use the $\mathrm{CO}_{2}$ and heat generated during the production process to grow algae, and to use them to make biofuel [10]. Or use the heat generated during manufacturing to supply district heating water? In Luleå (Sweden), a steel plant in continuous operation obtains an increase of the overall fuel energy yield from $30-40 \%$ to $60-80$ $\%$ by using the district heating network as a cooling sink, together with co-generated heat and electricity. [11]

Finally, altogether new processes may allow zero emissions steel production. HYBRIT, currently under final development, aims to substitute the blast furnace with a Direct Reduction process, using hydrogen generated with zero emission electricity (hydroelectric), followed by electric furnace treatment of the iron sponge obtained, to obtain zero emissions steel $[4,12]$.

\section{DISCUSION}

The metallurgical industry is an important contributor to energy use, $\mathrm{CO}_{2}$ emissions and other sustainability indicators.

Although demand for steel is expected to rise substantially, this industry still has many opportunities to contribute to achieve the IPCC climate change targets, by adopting a series of measures, as described earlier:

Better use of energy and increased use of low carbon energy. Increased use of scrap metal and better recycle of the remaining. Better design for reduced metal demand (less metal, lasting longer). Integration with other services or industries for extra efficiency, etc.

Even though the challenges are high, several examples have been offered that prove that the metallurgical industry has historically been a very innovative industry and is undoubtedly able to raise to turn these challenges into profitable opportunities.

Many of the changes needed imply new investments and a measure of redesign of current processes. However, we are looking at a 30-year endeavour, and therefore, it is feasible to plan ahead and include the necessary changes in the strategic planning of a company. In the end, all these changes aim to produce more and better products, using less material, less energy, finding a use for resources that are now mostly wasted and polluting less and therefore, in the long run it should simply make business sense to implement them.

\section{CONCLUSION}

This article has looked into the challenges and opportunities that the metallurgical industry faces in the coming years and decades, and its role as an important contributor to several sustainability indicators, like raw materials and energy use, greenhouse gas emissions and others.

Although demand for steel is expected to rise substantially, this industry still has a number of opportunities to contribute to the achievement of the IPCC climate change targets for 2050. Several examples have been offered as well, as instances of the innovativeness of this industry and its capability to turn these challenges into profitable opportunities.

While many of the changes needed imply ambitious new investments and a measure of redesign of current processes, the industry is looking at a 30 year endeavour, and therefore, it is feasible to plan ahead and include the necessary changes in the strategic planning of the company.

In the end, the advocated changes aim to produce more and better products, using less raw material, less energy, finding a use for resources that are now mostly wasted and polluting less (and at the same time helping save the planet by fulfilling the IPCC targets) and therefore, in the long run it should simply make business sense to implement these changes. 


\section{REFERENCES}

[1] THE ECONOMIST. Business and Climate: Hot, unbothered. 2019. Issue February 23rd. pp.13-14.

[2] INTERGOVERNMENT PANEL ON CLIMATE CHANGE. IPCC AR6 Report. [online]. [viewed 2019-02-22]. Available from https://www.ipcc.ch/report/Sixth-assessment-report-cycle/

[3] ALLWOOD, J., CULLEN, J. Sustainable Materials. UIT Cambridge, 2015.

[4] THE ECONOMIST. Decarbonising Industry. Coke fiends. Technology Quarterly. 2018. Issue December 1st. pp. 9-10.

[5] ALLWOOD, J. M., ASHBY, M. F., GUTOWSKI, T. G., WORRELL, E. Material efficiency: A white paper. Resources, Conservation and Recycling. 2011. vol 55, no. 3, pp. 362-381.

[6] MILFORD, R. L., ALLWOOD, J. M., CULLEN, J. M. Assessing the potential of yield improvements, through process scrap reduction, for energy and $\mathrm{CO} 2$ abatement in the steel and aluminium sectors, Resources, Conservation and Recycling. 2011. vol. 55, no. 12, pp. 1185-1195.

[7] CULLEN, J. M., ALLWOOD, J. M., BORGSTEIN, E. H. Reducing Energy Demand: What Are the Practical Limits? Environmental Science \& Technology. 2011. vol. 45, no. 4, pp. 1711-1718.

[8] WORRELL, E., PRICE, L, NEELIS, M., GALITSKY, C., ZHOU N., World best practice energy intensity values for selected industrial sectors, University of California, LBNL-62806. 2008. [online]. [viewed 2019-02-22]. Available from http://escholarship.org/uc/item/77n9d4sp.pdf

[9] ZANDI, M., ZIMMERMAN, W. Steel plant CO2 sequestration using high efficiency micro-algal bioreactor. In METEC 2011, Düsseldorf, Germany, 2011.

[10] LULEA TEKNISKA UNIVERSITET. Lulea District Heating. [online]. [viewed 2019-02-22]. Available from https://www.Itu.se/research/subjects/EISLAB-industriell-elektronik/2.56670/Fjarrvarme-1.85214?l=en

[11] HYBRIT. Fossil-free Steel - Hybrit. [online]. [viewed 2019-02-22]. Available from http://www.hybritdevelopment.com/ 